\title{
3Ps- Path, Pace and Pattern of Recovery from COVID-19 for Different Businesses in Indian Market
}

\author{
Sandeep Pandey \\ President- Product \& Strategy \\ Wavemaker (a WPP Co.) \\ Gurugram, India
}

\author{
Snigdha Gupta \\ Head of Analytics \& Data Science \\ Wavemaker (a WPP Co.) \\ Gurugram, India
}

\author{
Shubham Chhajed \\ Senior Data Scientist \\ Wavemaker (a WPP Co.) \\ Gurugram, India
}

\begin{abstract}
COVID-19, outbreak since December 2019, has impacted more than 150 countries as of May 2020. The uncertainty prevails with no cure and vaccine for this pandemic, and the economic situation worsens globally. Indian economy contracts as this uncertainty prolongs. Companies and business need a proper data driven guidance system to suggest their recovery trajectory and also give them optimal prioritization of their resources and operations to reduce unnecessary cash burn and sustain themselves in these unforeseen times. This should be addressed by looking into all local and global economic parameters, current market dynamics, consumer purchase intent and shift in behavior. Ensemble framework to integrate various econometric models, and mathematical constructs are used to further simulate various shock/stress scenarios to identify the pace and path to recovery for different businesses in the short-term and longterm perspectives. Hence this paper attempts at quantifying the impact of COVID-19 on different business sectors and their comeback strategy by analyzing all different self/competitive/market indicators.
\end{abstract}

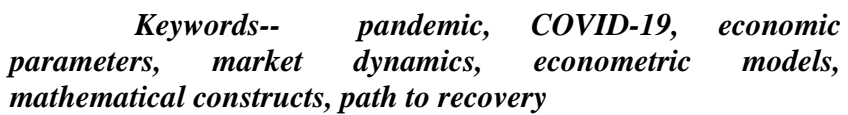

\section{INTRODUCTION}

COVID-19 has moved the lives of many across the world. This epidemic has been raised to Pandemic on 11 March 2020 by WHO. The post COVID-19 world could be entirely different. With rapid rise in COVID-19 cases across the world with little or no signs of saturation, even worst, it has claimed around 434K lives worldwide. Countries which have moved into lockdown to control the spread, have slowly began to ease due to piling up losses and economic breakdown. The entire supply chain is disrupted, demand is all in vain and we observe a huge shift in consumer behavior. Consumers are now much more cautious of their spending. All this has impacted the complete business dynamics, with many businesses running out of cash as the consumers short term purchase is focused towards essentials. As the uncertainty prevails and situation worsens the businesses are in dire need of data driven strategic guidance system to effectively channelize their recovery. The economy of a country and the stock markets play a pivotal role in the health of a business and vice versa. To gauge the direction and pace of recovery one needs to analyze the purchase behavior and drivers- further build a design of experiment and simulate stress scenarios with change in exogenous economic parameters and estimate the market potential and demand by using search trends as proxy.

During the COVID-19 times we have seen speculations and varied economic recovery paths varying with the increase in the length of national lockdown, national export import trade balance, unemployment rate, industrial manufacturing and supply units, macro-economic parameters like- inflation, GDP, CPI, Repo rate, Interest rate, currency in circulation, national policies, global economic factors and many more.

We observe a huge variability in these economic parameters hence the businesses today need much more customized approach to address their path for recovery basis their category and portfolio mix. One that is tailored to their specific operating conditions and the impact they face due to this adverse situation on their sales and production, resulting in the shift in consumer demand and the investor/ market sentiment.

India faces disruptive economic impact of the 2020 coronavirus pandemic onset. The World Bank and Rating agencies have revised India's growth for FY2021 with the lowest figures that India would have seen in past three decades since India's economic liberalization in the 1990s. One would have expected a respite after the announcement of the economic relief package in mid-May 2020, however India's GDP estimates were downgraded even further to negative figures, signaling a deep recession. On 26 May 2020, CRISIL announced that this will perhaps be India's worst recession since independence. State Bank of India research estimates a contraction of over 40 per cent in the GDP in Q1 FY21. [1]

Within a month of lockdown, unemployment rose from 6.7 per cent on 15 March 2020 to 26 per cent on 19 April 2020. During the lockdown, an estimated 14 crore (140 million) people lost employment. ${ }^{[2][3]}$ More than 45 per cent of households across the country have reported an income drop as compared to the previous year. ${ }^{[4]}$ The Indian economy was expected to lose over INR 32,000 crore (US\$4.5 billion) every day during the first 21-days of complete lockdown, which was declared following the coronavirus outbreak. ${ }^{[5][6]}$ Under complete lockdown, less than a quarter of India's \$2.8 trillion economic movement was functional. ${ }^{[7]} \mathrm{Up}$ to 53 per cent of businesses in the country were projected to be significantly affected. ${ }^{[8]}$ Supply 
chain experienced further stress with the lockdown restrictions in place.

Companies and business need a proper guidance system to suggest their recovery trajectory and also give them optimal prioritization of their resources and operations to reduce unnecessary cash burn and sustain themselves. Basis the macroeconomic forecasts, consumer intent, sectoral penetrations and stock market movement we have designed an amalgamated highly customized simulator and analytical case study to identify the 3Ps path, pattern and pace of the recovery in the most optimal way tailored to businesses and categories. This paper first attempts to describe the existing models and scenarios including economic recovery shapes, nowcasting and dynamic stochastic general equilibrium models and then the tailored simulations and analysis using ensemble methods we have designed for categories and businesses for recovery.

\section{EMPIRICAL FRAMEWORK}

Large economic forums including the IMF, RBI and various rating agencies etc. have been using nowcasting to forecast GDP and other macroeconomic projections for the current and near future. Due to the huge variability in the data the agencies have been updating the results frequently.

Nowcasting is a very powerful technique and as the name suggests it's about predicting the present, the recent past and the near future. Nowcasting has long been done by economists using methods that allow the use of mixedfrequency data and intermittent releases. The older methods do not specify joint distributions and in general are variablespecific, often without a model structure tying together nowcasts across variables or over time as data become available. It exploits information from different parameters and data series at different time period and with different publication lags. The idea is that signals about the direction of change in economic parameter can be extracted from this large and heterogeneous set of information sources (such as unemployment figures, industrial orders, trade balances, etc..) before economic factors are published.

Models used for Nowcasting:

1.) Simple benchmark, we use a univariate AR model:

$$
y_{t}=\alpha_{0}+\alpha_{1} y_{t-1}+u_{t}-------- \text { (1) }
$$

where $\alpha_{0}$ and $\alpha_{1}$ are parameters and $u t$ is the residual term.

2.) Unfolding Nowcasters: Each indicator is a combination of a limited number of components, each of which is a mixture of a shortlist of time-series. Say $\mathrm{x}_{\mathrm{t}}^{\mathrm{i}, \mathrm{j}}$ is the observation at time $t$ of the ith time series incorporated in the jth component of a given nowcaster. $\mathrm{C}_{\mathrm{t}}^{\mathrm{j}}$, the value of the jth component at time $\mathrm{t}$, is then computed as follows: ${ }^{[9]}$

$$
c_{t}^{j}=\frac{1}{I_{j}} \sum_{i=1}^{I_{j}} x_{t}^{i, j}-----------
$$

where $I_{j}$ is the number of time series used to build the jth component. The $\mathrm{x}_{\mathrm{t}}^{\mathrm{i}, \mathrm{j}}$ are scaled time series: the original time series can have different scales, such as rates of variation or headline indicators. Scaling every data series makes them comparable so that they can be summed as in the above equation. Finally, the value for a given nowcaster $\mathrm{N}_{\mathrm{t}}$ at time $\mathrm{t}$ is given by the following formula: ${ }^{[9]}$

$$
N_{t}=\frac{1}{I_{N}} \sum_{j=1}^{I_{N}} c_{t}-------------
$$

where $I_{N}$ is the number of components associated with the nowcasting indicator.

Dynamic Stochastic General Equilibrium Modelling (DSGE) method in macroeconomics, attempts to explain economic phenomena, such as economic growth and business cycles, and the effects of economic policy, through econometric models based on applied general equilibrium theory and microeconomic principles. This is another method used to forecast GDPs considering acute shocks to the economy. Thus, these models are used to simulate the different stress scenarios. Its structural in nature and helps explicitly projecting the macro-economic scenarios in response to various parameters.

Constructing DGSE Model equations:

1.) Under perfect competition, firms produce goods basis the demand

$$
y_{t}=e^{z_{t}}\left(k_{t}\right)^{a}\left(n_{t}\right)^{1-\alpha}---------(4)
$$

where $\mathrm{y}_{\mathrm{t}}$ denotes output and $\mathrm{k}, \mathrm{n}$ and $\mathrm{z}$ denote the capita, labor and technology indices respectively.

2.) Macroeconomic Part: The exogenous macroeconomic variables are $\mathrm{Y}_{\mathrm{t}}, \mathrm{P}_{\mathrm{t}}$ (price indices) and $\mathrm{R}_{\mathrm{t}}{ }^{\mathrm{n}}$ (return indices). Although we can take these variables simply as being exogenous, we have to take care that they are mutually affected in the general equilibrium. Therefore, if one wants to simulate the effects of national level shocks on the economy, one must construct a macroeconomic model.

To endogenize macroeconomic variables, for simplicity, we use the dynamic

IS-LM ("investment-savings" and "liquidity preference-money supply") model, which consists of three equations: dynamic IS curve (the Euler equation), dynamic LM curve (the Taylor rule), and new-Keynesian Philips curve. Of course, we can also utilize a full blown DSGE model. Typically, the dynamic IS-LM model is expressed as follows:

$$
\begin{array}{r}
E_{t}\left[\hat{Y}_{t+1}\right]+E_{t}\left[\hat{\pi}_{t+1}\right]=\hat{Y}_{t}+\hat{R}_{t}^{n}-----(5) \\
\hat{\pi}=\beta E_{t}\left[\hat{\pi}_{t+1}\right] \kappa \hat{Y}_{t}+\varepsilon_{t}^{s}-----(6) \\
\hat{R}_{t}^{n}=\psi \hat{\pi}_{t}+\varepsilon_{t}^{R}--------(7)
\end{array}
$$

where " $\wedge$ " denotes the deviation from the steady state value $\varepsilon^{\mathrm{s}}$ and $\varepsilon^{\mathrm{R}}$ are supply shock and monetary policy shock, respectively. ${ }^{[10]}$

\section{A. Methodology}

We have analyzed and run multidimensional simulations which include the core principles of the above stated models along with Bayesian regression model. In a recent analysis, economists Hugo Erken, Raphie Hayat and Kan Ji view the COVID-19 shock as a black swan event where the occurrence of the event might be unlikely, but its impact is big. In trying to assess the pandemic's impact on India's GDP, they use a designed scenario-building model, which is often used as a methodological tool in many disaster impact assessments. Hence, we simulate numerous business constructs by varying input of the various 
economic parameters. A test and validation framework is built on historical 4 year data from 2015 till 2019.

Stocks movement data is a good indicator of the current market dynamics, is used to analyze the financial status of businesses and domains/ sectors. For the scope of this paper we have analyzed NSE (National stock exchange) and BSE (Bombay stock exchange) sectoral indices for the last one year. This is then used to derive statistical indices and impact ranking order on the recovery patterns and investor/ market sentiments towards businesses/ domains/ categories, economic policies and national relief packages to revive economy. The statistical indices method developed here, looks at the latest 6-month stock performance, hence analyzing the period before and during COVID-19 to draw comparative conclusions. it's a moving window analysis designed and executed for each business and category independently/ individually to generate their immediate recovery (short term) path, direction, and hence concluding the pace of recovery in long term for that business segment.

The businesses and companies individually have different operating setups, portfolio mix and market penetration, hence one should expect each to have its own pace of recovery. Some would be ahead of the category curve while some would still need to find the right strategy to get started on the recovery path. Thence we have further used the macroeconomic simulator discussed above to then regress sales as our dependent variable with different economic parameters to analyze individual business rebound strategy with the change in economic parameters and variability in moving timeframe.

The stocks statistical index and sales macroeconomic simulator are then statistically ensembled to design the strategy and guidance system for businesses and categories to suggest their recovery pace \& path and also give them optimal prioritization of their resources and operations.

With the flux in current national economic situation, Lockdown period has resulted in a huge shift in consumer purchase behavior. This shift could be observed in growth in online/ e-tail intent, surge in online education courses and demand, OTT consumption etc. Hence an important leg to this study is to estimate the shift in demand by different market segments to understand the complete market dynamics and potential recovery trajectory for each business segment, during and post COVID-19.

Despite developing these methods and validating them on the time series data from various sources, one still needs to establish and validate on the demand side. It must then be confirmed and aligned with consumer behavior and purchase intent. With the ever-increasing internet usage and consumption, numerous researches have proven time and again that the web search trend can be used as the proxy for intent to purchase. We have used google keyword search data which is further segmented by categories to analyze the consumer intent to purchase and top of mind awareness and consideration towards businesses and industries, to estimate the potential demand.

We further cross checked the outputs from ensemble models from simulator and the consumer intent, with the data for category penetration and consumer sentiments from TGBI research studies.

Mainly the search and the research data has helped us validate and coarse correct outcome from the economic simulations, overview of demand analysis and recovery scenarios.

\section{Algorithm1: Deriving Statistical stock index from: Initialize}

H0: There is no statistically significant variation in the datasets for COVID-19 and non COVID-19 period and hence the models developed for COVID-19 and nonCOVID-19-time duration does not capture any variation in short term

Method: Time Series stocks data (sector indices) Regressive models (Time series lagged data)

Result: The variation in the time series coefficients and the distribution of the residuals rejects or accepts $H O$.

If $(\mathrm{HO}$ rejected $)$ :

Derived Sectoral Index Scores $=$ fn(Relative Sectoral index pre COVID-19, Relative Sectoral Index during COVID-19) Else: Statistically derived Index is not significant

End

Algorithm2: Sales and Macroeconomic Simulations

Initialize:

Method:

1.) Sales Bayesian Structural Model (economic parameters)

2.) Final Result $\sim$ fn(Result from 1 and Derived Stocks Sectoral Index)

3.) Sales and Growth Simulations basis the coefficients Result: Growth derived from the simulator basis IMF and RBI forecasted Numbers

End

B. Data Source

Table 1: Variable Descriptions and Source

\begin{tabular}{|l|l|l|}
\hline \multicolumn{1}{|c|}{ Section } & \multicolumn{1}{|c|}{ Parameters } & Source \\
\hline Sectoral indices & Stocks & Nieck Exchange data NSE/ BSE \\
\hline Industry financial metrics & Sales and financial projections & Company financial reports \\
\hline Pandemic progression & $\begin{array}{l}\text { Virus spread related parameters: \# infected daily cases, \# recovered, } \\
\text { \# quarantined, Identified Hotspots and parameters }\end{array}$ & Indian council of medical research \\
\hline \multirow{5}{*}{ Economic parameters } & GDP & Reserve Bank of India published data \\
\cline { 2 - 2 } & Inflation & \\
\cline { 2 - 3 } & CPI & \\
\cline { 2 - 3 } & Disposable income/ Per Capita PPP \\
\cline { 2 - 3 } & Interest Rates/ Bank Rate/ Savings rate \\
\cline { 2 - 3 } & Survey Inflation Expectation & \\
\cline { 2 - 3 } & Survey Consumer Confidence Index \\
\hline
\end{tabular}




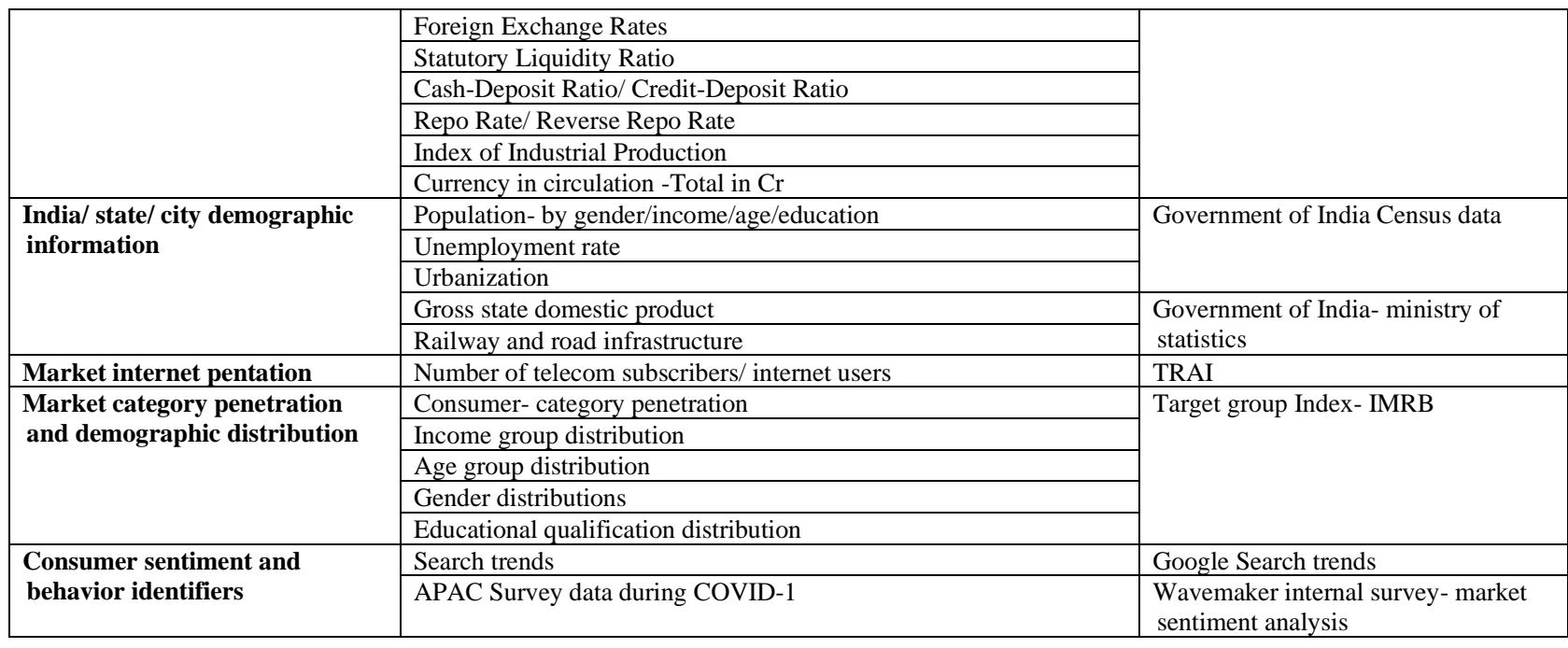

Economic indicators are key measures to the country's economic condition, that can help better understand its pace and direction in short term and long term. These indicators can help investors decide on their strategic investments and future planning. Economic indicators can help understand the market dynamics, as well as other important financial factors.

Economic indicators have been classified into two major categories basis the timing in relation to the business cycle: leading indicators and lagging indicators. ${ }^{[1]}$

Leading indicators: Indicators that usually reflect change along with the economy and therefore are useful as short-term predictors of the economy. Some of the leading indicators include: Retail Sales, Stock Price Movement, Industrial Activity, Inventory Balance etc. ${ }^{[12]}$

Lagging indicators: Lagging indicators usually change after the economy as a whole does. These are generally most helpful in identifying and confirming specific economic patterns which then can be used to make economic predictions. Some of the lagging indicators include: Gross Domestic Product(GDP), Disposable Income, Unemployment Rate, Consumer Price Index (CPI/ Inflations rates), Interest Rates etc.

One would agree that not all parameters impact your business equally, some would have an immediate significant effect, while some could have a delayed prolong decay effect. Hence it is important to understand the individual parameter effect on different businesses and their pecking order or importance. Some of the major economic parameters include: $:^{[12]}$

1. Gross Domestic Product (GDP): GDP is the market value of all goods and services produced in a nation during a specific time period. GDP is widely accepted as the primary indicator of macroeconomic performance. The GDP, as an absolute value, shows the overall size of an economy, while changes in the GDP, often measured as real growth in GDP, show the overall health of the economy. GDP of India (USD 2.7 Trillion, Source: World Bank, 2018)

2. Consumer Purchasing Index (CPI): This measure is the best indicator of inflation. It could be considered as one of the most used/ watched after parameter by financial institutions while designing fiscal policies and implementation. The CPI is the measure of change in the prices paid for goods and services by urban consumers for a specified month.

3. Producer Price Index (PPI): The PPI is a group of indices that measures the change in the selling price of goods and services over a period of time. Think of it as the businessside equivalent to the CPI that measures changes in prices paid by consumers: The PPI captures price movements at the wholesale level.

4. M2 (Money Supply): It is a measure of money supply that includes cash, checking deposits, and easily convertible near money.

5. Consumer Confidence Survey: A gauge of the public's confidence about the health of the economy that reflects the public's optimism/pessimism and the nation's mood. This measure is an indicator of consumer spending, they would spend higher when they are confident about their financial and employment prospects.

6. Stock Market Index: Stock prices are partially based on what companies are expected to earn. With accurate earnings estimate, the stock market movement can indicate the pace and direction of the economy. For example, a down market could indicate that overall company earnings are expected to decrease and the economy could be headed toward a recession. On the other hand, an up market could suggest that earnings estimate will rise and therefore the economy as a whole may be thriving.

7. Unemployment: The number of jobs created or lost in a month is an indicator of economic health and can significantly impact the markets economy. When more businesses are hiring, it suggests that businesses are performing well. More hiring can also lead to assumption that more people will have more money to spend.

8. Interest Rates: It is a lagging indicator of economic growth. When interest rates increase, it discourages consumers from taking on debt and businesses from expanding, and as a result, GDP growth may become stagnant. If interest rates are too low, that can lead to an increased demand for money and raise the likelihood of inflation. Raising inflation can distort the economy and 
the value of its currency. Current interest rates are indicative of the economy's current condition, and can also suggest where the economy might be headed.

9. Currency Strength: It is a lagging indicator. When a country has a strong currency, its purchasing and selling power with other nations is higher. A country with a strong currency can import products at a cheaper rate and sell its products overseas at higher foreign prices. However, when a country has a weaker currency, it can draw in more tourists and encourage other countries to buy its goods since they are cheaper.

10. Retail sales: This measure tracks consumers personal consumption across retail industries and track growth or deceleration of personal consumption spending. This is a very important parameter to assess businesses growth.

\section{Data grain limitation and proposed approach}

The country is going through unprecedented times, experiencing huge variability in the economic front. There exists no such past study/experience of this kind or even of the scale, hence there is a huge dependency on test and learn experimentation frameworks. Apart from this due to the difference in reporting of different sources, the stated and available grain of different economic parameters vary widely. Hence it poses difficulty, to confine all the economic parameter at the same grain. Furthermore, there exist interdependency of different economic parameters on one another. And one needs to use different mathematical constructs to confine the error propagation if one uses these parameters together. We have deployed independent hierarchical structural analysis construct to handle and limit the excess errors arising from in this situation.

\section{EMPIRICAL RESULTS}

As of $31^{\text {st }}$ May 2020, the total number of COVID19 cases in India stands at 190K (refer Table1, Figure1) and is seeing an exponential increase and records as high as $10 \mathrm{~K}$ cases per day now. As shown in the indexed chart (refer Figure2) and COVID-19 case density table (refer Table2) Delhi, Maharashtra, Tamil Nadu and Gujarat records high COVID-19 case density.

Table 2: COVID cases in India by state

\begin{tabular}{|c|c|c|c|c|c|c|c|c|c|c|}
\hline \multirow[b]{2}{*}{ States } & \multicolumn{10}{|c|}{ Actual Cases in India- Weekly Numbers till 31st May 2020} \\
\hline & $\begin{array}{l}\text { W14 } \\
\text { (29th } \\
\text { March } \\
2020)\end{array}$ & W15 & W16 & W17 & W18 & W19 & W20 & W21 & W22 & $\begin{array}{l}\text { W23 } \\
(31 s t \\
\text { May } \\
2020)\end{array}$ \\
\hline India & 3,072 & 7,529 & 14,792 & 24,893 & 37,157 & 59,662 & 85,710 & 125,101 & 173,763 & 190,535 \\
\hline Maharashtra & 490 & 1,574 & 3,323 & 6,817 & 11,506 & 19,063 & 29,100 & 44,582 & 62,228 & 67,655 \\
\hline Tamil Nadu & 411 & 911 & 1,323 & 1,755 & 2,526 & 6,009 & 10,108 & 14,753 & 20,246 & 22,333 \\
\hline Delhi & 445 & 903 & 1,707 & 2,514 & 3,738 & 6,318 & 8,895 & 12,319 & 17,386 & 19,844 \\
\hline Gujarat & 105 & 308 & 1,272 & 2,815 & 4,721 & 7,402 & 9,931 & 13,268 & 15,934 & 16,779 \\
\hline Rajasthan & 200 & 553 & 1,229 & 2,034 & 2,666 & 3,579 & 4,727 & 6,494 & 8,365 & 8,831 \\
\hline Madhya Pradesh & 104 & 443 & 1,355 & 1,952 & 2,719 & 3,341 & 4,595 & 6,170 & 7,645 & 8,089 \\
\hline Uttar Pradesh & 174 & 433 & 969 & 1,778 & 2,328 & 3,214 & 4,057 & 5,735 & 7,284 & 7,823 \\
\hline West Bengal & 69 & 126 & 287 & 571 & 795 & 1,678 & 2,461 & 3,332 & 4,813 & 5,501 \\
\hline Bihar & 30 & 60 & 85 & 228 & 471 & 571 & 1,018 & 2,177 & 3,376 & 3,815 \\
\hline Andhra Pradesh & 161 & 381 & 603 & 1,061 & 1,463 & 1,887 & 2,307 & 2,709 & 3,436 & 3,679 \\
\hline Karnataka & 128 & 214 & 371 & 489 & 589 & 753 & 1,056 & 1,743 & 2,781 & 3,221 \\
\hline Telengana & 159 & 504 & 791 & 984 & 1,039 & 1,133 & 1,454 & 1,761 & 2,425 & 2,698 \\
\hline Punjab & 57 & 132 & 202 & 298 & 480 & 1,731 & 1,935 & 2,029 & 2,197 & 2,263 \\
\hline Haryana & 49 & 177 & 225 & 272 & 360 & 647 & 818 & 1,067 & 1,721 & 2,091 \\
\hline Assam & 24 & 29 & 35 & 36 & 43 & 59 & 90 & 259 & 1,024 & 1,272 \\
\hline
\end{tabular}

Source: https://www.kaggle.com/sudalairajkumar/covid19-in-india 
Figure 1: Rise of COVID cases in India

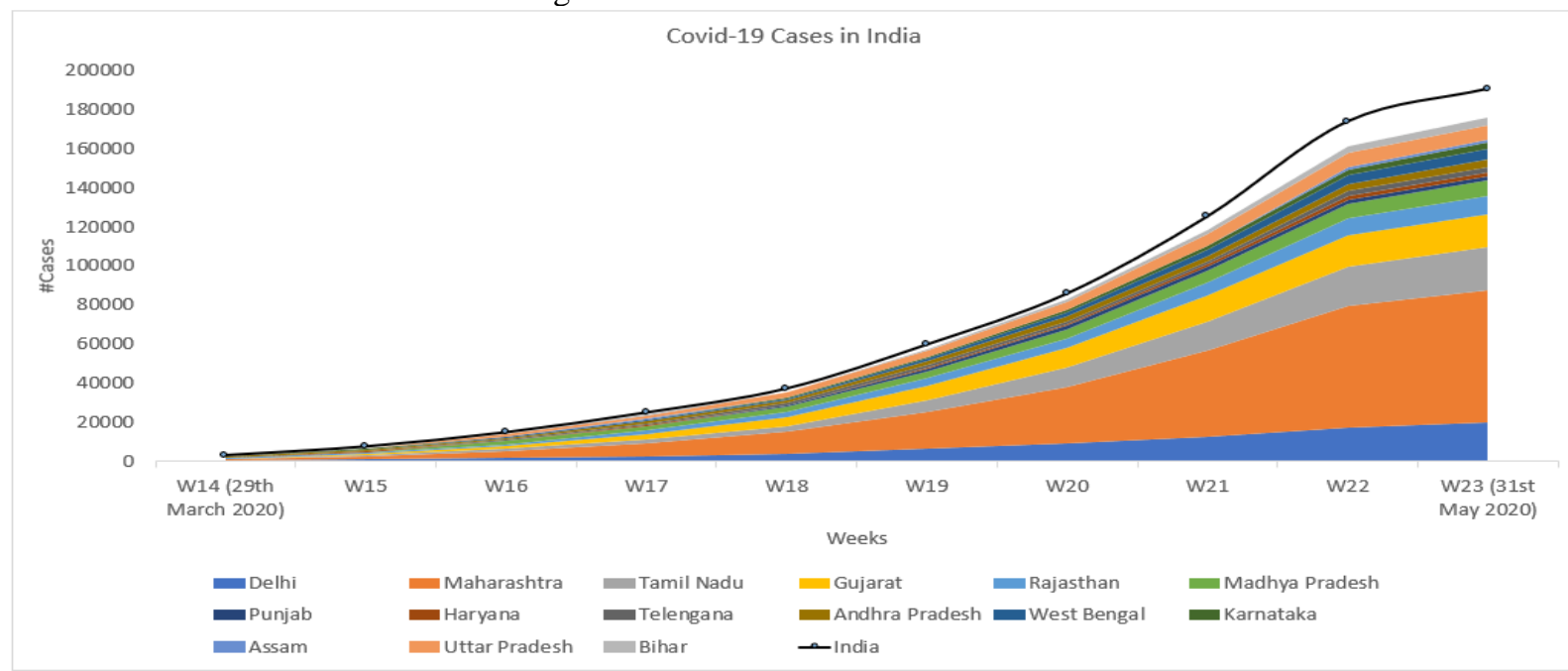

Source: https://www.kaggle.com/sudalairajkumar/covid19-in-india and https://www.mohfw.gov.in/

Figure 2:Indexed COVID case density per 1000 people

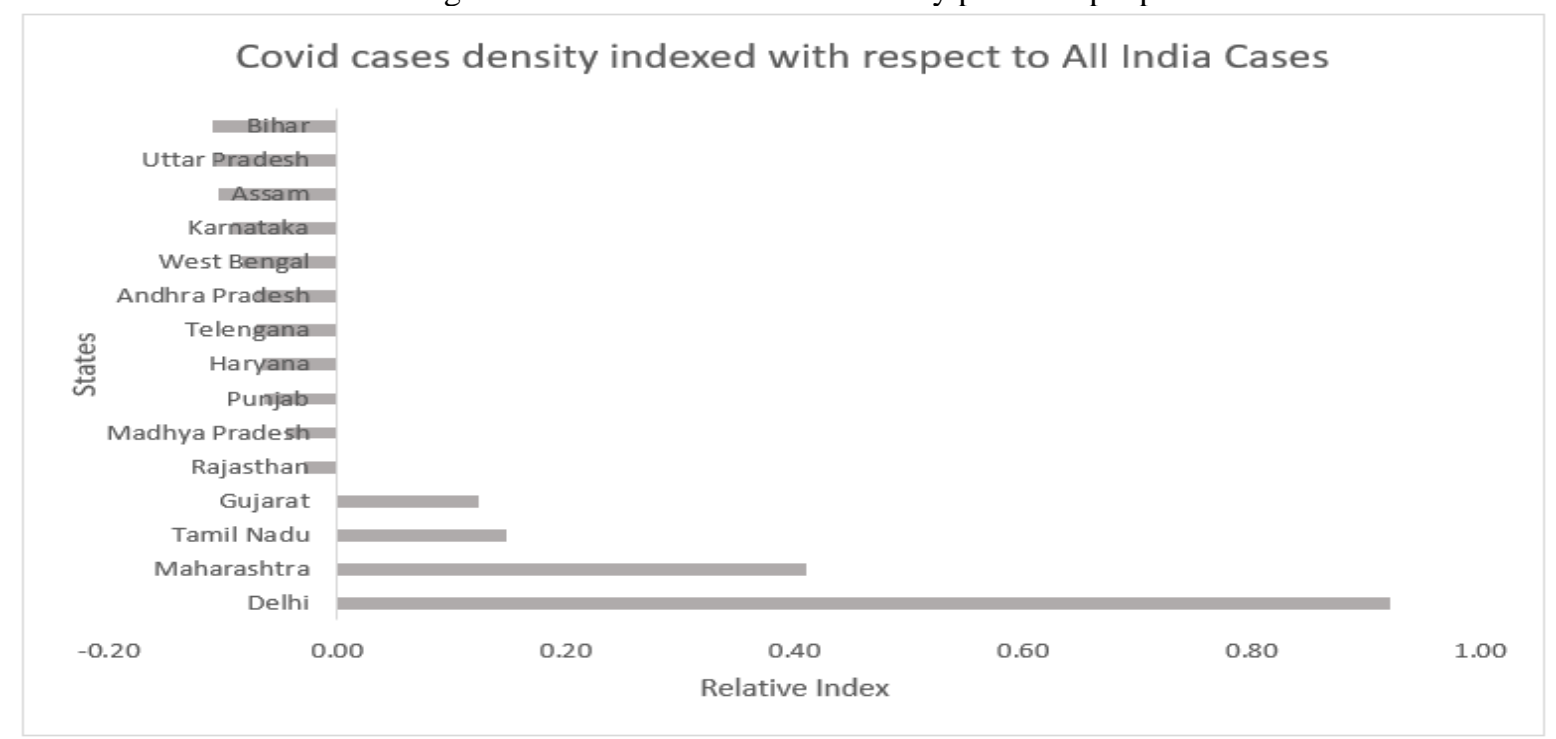

Source: https://www.mohfw.gov.in/

Table 3: COVID-19 actual case density by states

Source: https://www.mohfw.gov.in/

\begin{tabular}{|l|r|}
\hline & $\begin{array}{l}\text { Covid Cases } \\
\text { Density(per } \\
\text { 1000 people) } \\
\text { [As of 31st May } \\
\text { 2020] }\end{array}$ \\
\hline States & 0.14 \\
\hline India & 1.06 \\
\hline Delhi & 0.55 \\
\hline Maharashtra & 0.29 \\
\hline Tamil Nadu & 0.26 \\
\hline Gujarat & 0.11 \\
\hline Rajasthan & 0.09 \\
\hline Madhya Pradesh & 0.08 \\
\hline Punjab & 0.07 \\
\hline Haryana & 0.07 \\
\hline Telengana & 0.07 \\
\hline Andhra Pradesh & 0.06 \\
\hline West Bengal & 0.05 \\
\hline Karnataka & 0.04 \\
\hline Assam & 0.03 \\
\hline Uttar Pradesh & 0.03 \\
\hline Bihar &
\end{tabular}


Due to the large geographic span and varying population density, we observe huge variability in the increase in COVID-19 cases across different states in India. For Indian economy comeback, with this huge diversity and exponential increase in cases, it is very important to look at the possible pace and path to recovery of economy by geographic segments and further understand the supplydemand revival to better plan the comeback strategy.

Stock market dynamics play a pivotal role in suggesting the short-term movement of sectors/category/company and thus the economy of the country.

Unfortunately, there is no readily available equation that tells us the movement in the stock prices and market movement. That said, we do know a few things about the forces that move a stock price up or down. These forces fall into three categories: fundamental factors, technical factors, and market sentiment. ${ }^{[13]}$

Fundamental factors drive stock prices based on a company's earnings and profitability from producing and selling goods and services.

Technical factors relate to a stock's price history in the market pertaining to chart patterns, momentum, and behavioral factors of traders and investors. Things would be easier if only fundamental factors set stock prices. Technical factors are the mix of external conditions that alter the supply of and demand for a company's stock. Some of these indirectly affect fundamental factors.

Market Sentiment is perhaps the most vexing category. Market sentiment is being explored by the relatively new field of behavioral finance. The huge variation in the stock market, leads to the assumption that the markets are not stable over time, and this inefficiency can be explained by psychology and other social science disciplines. Some investors claim to be able to capitalize on the theory of behavioral finance. For the majority, however, the field is new enough to serve as the "catch-all" category, where everything we cannot explain is deposited. ${ }^{[13]}$

Investors interest in the market varies basis different macro and microeconomic parameters. Short-term investors and traders tend to prioritize technical factors. Vs. Longterm investors prioritize fundamental factors more and recognize that technical factors play an important role. Investors who believe strongly in fundamentals can reconcile themselves to technical forces with the following popular argument: technical factors and market sentiment often overwhelm the short run, but fundamentals will set the stock price in the long-run. In the meantime, we can expect more exciting developments in the area of behavioral finance, especially since traditional financial theories cannot seem to explain everything that happens in the market.

On Analyzing almost all the Nifty 50 sectoral indices for Pharma, Telecom, Automobile, FMCG, Realty, Media etc. and then in depth into the individual company stocks for the last 6 months, we have seen a strong upward movement in Pharma, FMCG and Telecom during COVID-19 times as the consumers and investors are much more focused on the essentials. With lockdown getting imposed in the country there is a huge hit in the Automobile, Realty and Media sector. (Pl. Refer figures 3,4,5 and 6)

Figure 3: Stock movement for different sectors

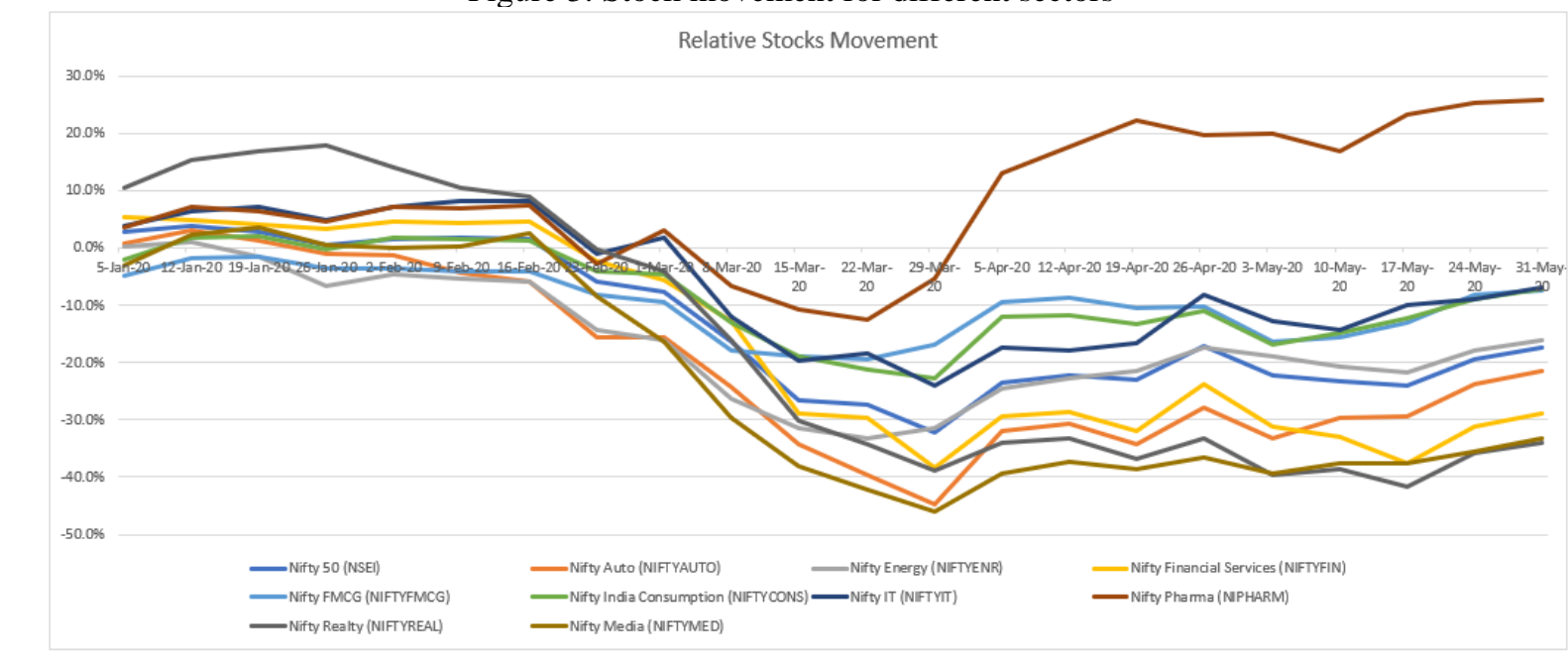

Source: https://www1.nseindia.com/ 
Figure 4: COVID vs Non-COVID indexed sectoral change with respect to market change

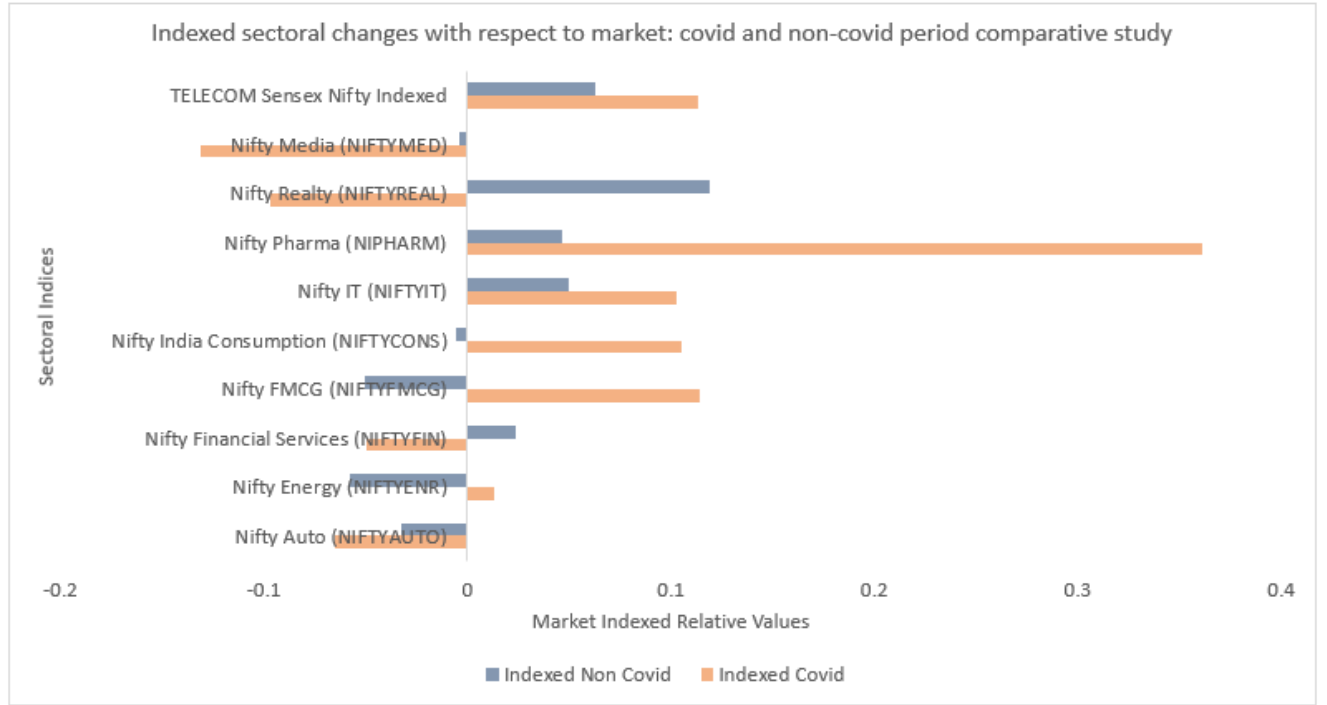

Source: $\underline{\text { htps://www1.nseindia.com/ and https://www.bseindia.com/ }}$

Figure 5: FMCG cluster movement (C1: Packaged foods, C2: Personal care and Beauty Segment and C3: Spirits and Beverages)

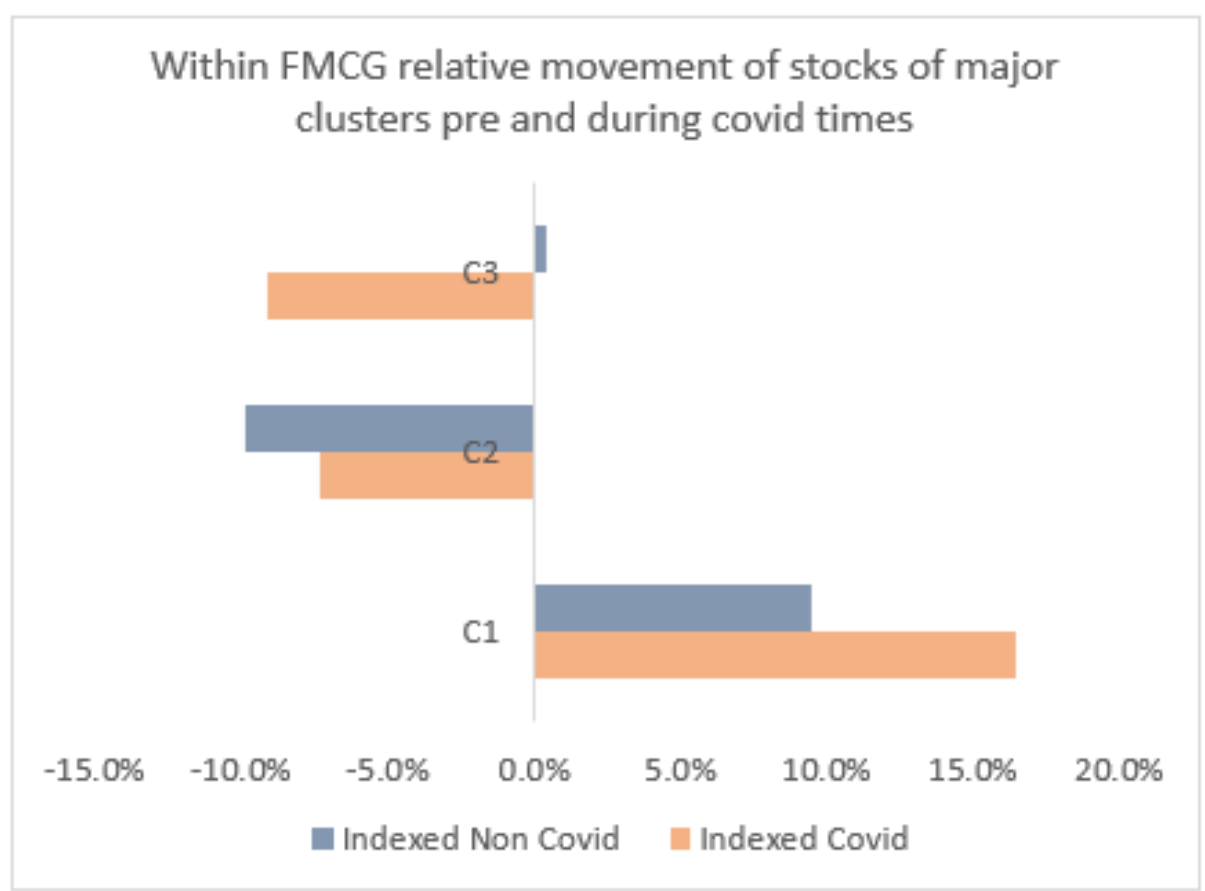

Source: https://www1.nseindia.com/ 
Figure 6: FMCG company stock movement

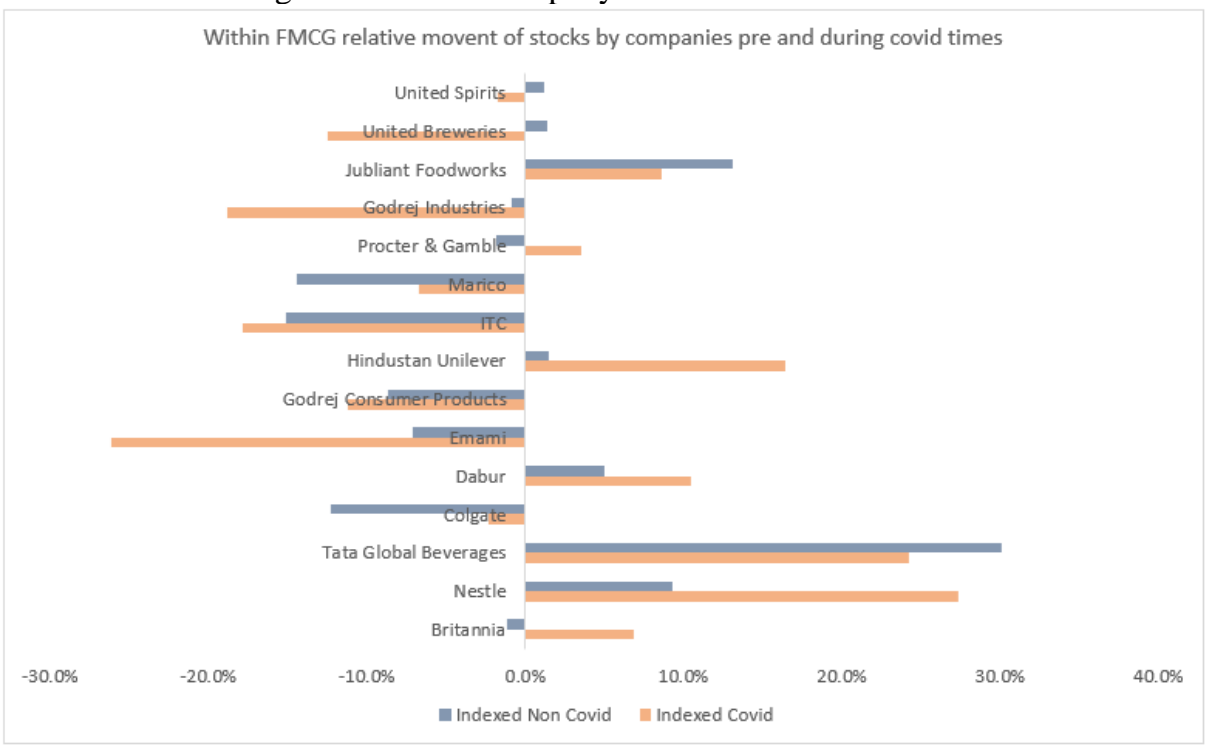

Source: https://wwwl.nseindia.com/

We have analyzed the variability at all the levels, starting at overall level for each sector followed by a sub level to analyze the sub sectors (as shown above for FMCG where C1: Packaged foods, C2: Personal care and Beauty Segment and C3: Spirits and Beverages) and then finally at each company level which is the lowest grain analyzed. Hence the stocks data is used to estimate the short-term movement and recovery patterns for businesses and companies.

Once we have analyzed the stocks movement, we then analyze using the macroeconomic simulations to understand the long-term impact on the category sales, growth and recovery.

Following are the simulations for Personal Care segment (Model estimates and outputs: Table4 and Figure 7) and the similar analysis is done for other segments like Pulses and Grain category, Automobiles, Telecom also.

Post multi-model ensemble we have developed a simulator that calculates the industry wide growth basis the economic forecasts (Industry projections: Table 5), in our case we have used IMF and RBI forecasts for GDP (as of $31^{\text {st }}$ May 2020 stands at 1.9 per cent growth forecasted by IMF) and inflation rate forecast by RBI. ${ }^{[14]}$

When companies and the general public perceive the economy to be strong, they are much more comfortable spending money. This spending in turn creates more demand for new and existing products and services. On the other hand, when there is doubt about the future direction of the economy, businesses and individuals will be more hesitant to spend money, preferring to "play it safe" until a brighter picture emerges. This can result in higher unemployment and less production. Companies often find they have overestimated their production needs and find they must cut back sharply as the economy slows. This serves to further act as a brake on overall economic growth. ${ }^{[15]}$
As we all know, variations in the different economic parameter gives us a clear picture of where and how the economy is moving and what will the outcome of this movement lead to.

We have analyzed more than 50+ economic parameters in our research. In table 4 we highlight the fifteen such factors that have come significant in driving the sales in personal care category. We have built a Bayesian regression induced DGSE framework to simulate the effect on sales due to the variation in these parameters. Interestingly from the simulation of CPI and Industrial index we can see rise in sales till the two parameters reaches the maxima and then starts declining. For CPI we have observed a fairly sharp fall in sales beyond 170 CPI Index. Due to COVID-19 the entire supply chain is disrupted; therefore markets have seen huge drops in the distribution of personal care products, thus the sales has also dropped. The simulator shows almost a linear trend between the distribution and sales. The major banking related parameters including the CDR, repo rate, SLR and savings rate shows an inverse trend with sales i.e. as with the increase in these parameters decline in sales is observed over a period of time. This is an essential piece of information in assessing the paths to recovery. For India the relief packages and the policies announced by Reserve Bank will significantly impact these parameters.

The gross domestic product (GDP) of a country is one of the primary measures of a country's economic performance. Markets and business sentiments are more secure and stable when the GDP rate is increasing, our research also concludes this hypothesis and is observed in our simulations where the sales increases significantly as the GDP increases. During the COVID-19 times the IMF and even the national agencies have revised their forecasts for the GDPs and have significantly dropped the numbers not just for India but the entire world. 
For the fact that supply and demand is the sole strategy for large number of businesses in a country like India, and the lack of unavailability of the recent data which actually shows the demand in the market, google search trends (like in the cases of early flu predictions etc.) can be instrumental in predicting the future purchase intent of the consumers.

Table 4: Macroeconomic simulator- model coefficients

\begin{tabular}{|c|c|c|c|c|}
\hline \multicolumn{5}{|c|}{ Macroeconomic Simulator Coefficient (Ensemble Methods) } \\
\hline Variable & $\begin{array}{l}\text { Personal care } \\
\text { and beauty }\end{array}$ & $\begin{array}{l}\text { Pulses and } \\
\text { Grains }\end{array}$ & $\begin{array}{l}\text { Automobil } \\
\text { e (2 } \\
\text { wheelers) }\end{array}$ & Telecom \\
\hline Urban Sectoral CPI & 0.894 & 0.193 & -0.083 & 0.550 \\
\hline Overall Wtd Dist Max & 0.325 & 0.749 & \multicolumn{2}{|c|}{ Not Available } \\
\hline $\begin{array}{l}\text { Average of Currency in } \\
\text { circulation-Total in } \mathrm{Cr}\end{array}$ & 0.643 & 0.810 & 0.186 & 0.341 \\
\hline Statutory Liquidity Ratio & -0.926 & -0.827 & -0.077 & -0.282 \\
\hline Credit-Deposit Ratio & 0.449 & 0.226 & 0.015 & 0.568 \\
\hline Policy Repo Rate & -0.553 & -0.633 & 0.6021 & 0.157 \\
\hline Bank Rate & -0.673 & & 0.0842 & 0.157 \\
\hline Savings Deposit Rate & -0.795 & 0.769 & -0.217 & -0.195 \\
\hline $\begin{array}{l}\text { INR-US\$ Spot Rate ( Rs. Per } \\
\text { Foreign Currency) }\end{array}$ & -0.585 & -0.052 & -0.293 & 0.507 \\
\hline Index of Industrial Production & 0.728 & 0.173 & -0.094 & 0.299 \\
\hline GDP at Basic Price in $\mathrm{Cr}$ & 0.969 & 0.801 & 0.766 & 0.52861 \\
\hline Inflation Year & -0.990 & \multirow{4}{*}{\multicolumn{3}{|c|}{$\begin{array}{l}\text { Included in the simulator with } \\
\text { data grain adjustment }\end{array}$}} \\
\hline $\begin{array}{l}\text { GDP per capita, PPP (current } \\
\text { international \$) }\end{array}$ & 0.995 & & & \\
\hline Unemployment Rate & -0.761 & & & \\
\hline Internet Users in Millions & 0.997 & & & \\
\hline
\end{tabular}

Figure 7: Macroeconomic parameter simulation/ sensitivity on sales as a business KPI
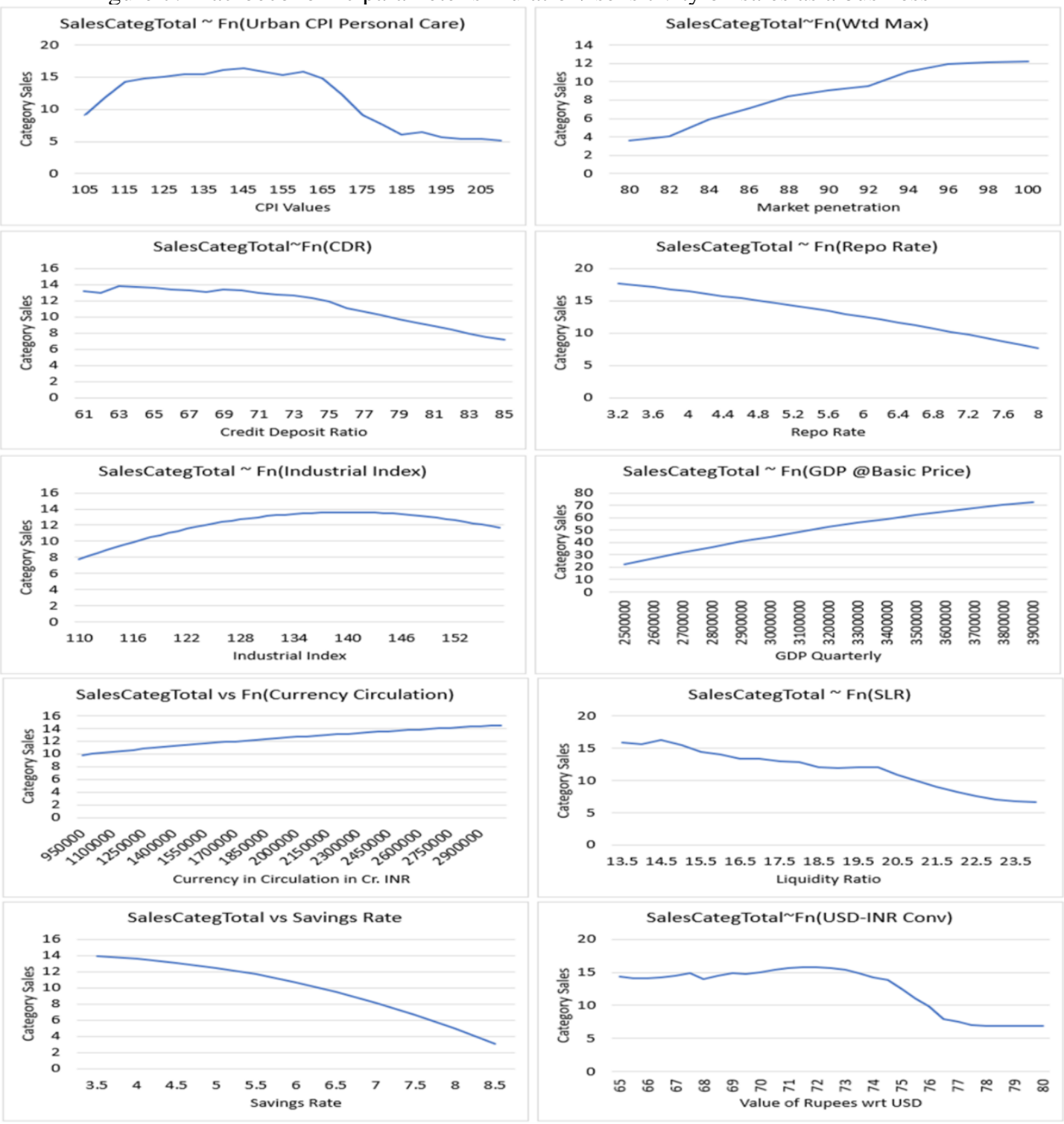
With the significant increase in internet usage in India in the past few years, we have used Google search data (refer Figure 8) as a proxy for consumer intent and demand, to cross validate our results for above sales/ growth projections.

Table 5: Simulated potential sales growth for FY-21

\begin{tabular}{|l|r|r|l|}
\hline Sectors & $\begin{array}{l}\text { Actual Growth } \\
\text { FY 19-20 }\end{array}$ & $\begin{array}{l}\text { Simulated Growth } \\
\text { basis IMF and RBI } \\
\text { forecasts for FY 20-21 }\end{array}$ & $\begin{array}{l}\text { Pace Drop in } \\
\text { Growth }\end{array}$ \\
\hline $\begin{array}{l}\text { Cosmetics and } \\
\text { Personal Care }\end{array}$ & $7.32 \%$ & $4.1 \%$ & $-44 \%$ \\
\hline Food and staples & $11.6 \%$ & $9.3 \%$ & $-20 \%$ \\
\hline $\begin{array}{l}\text { Automobile 4 } \\
\text { Wheelers }\end{array}$ & $-17.0 \%$ & $-39.0 \%$ & $-129 \%$ \\
\hline $\begin{array}{l}\text { Automobile 2 } \\
\text { Wheelers }\end{array}$ & $-14.0 \%$ & $-35.0 \%$ & $-150 \%$ \\
\hline Telecom & $0.80 \%$ & $0.60 \%$ & $-25 \%$ \\
\hline
\end{tabular}

Figure 8: Google search trend for different categories

\section{Indexed google search trend by categories}

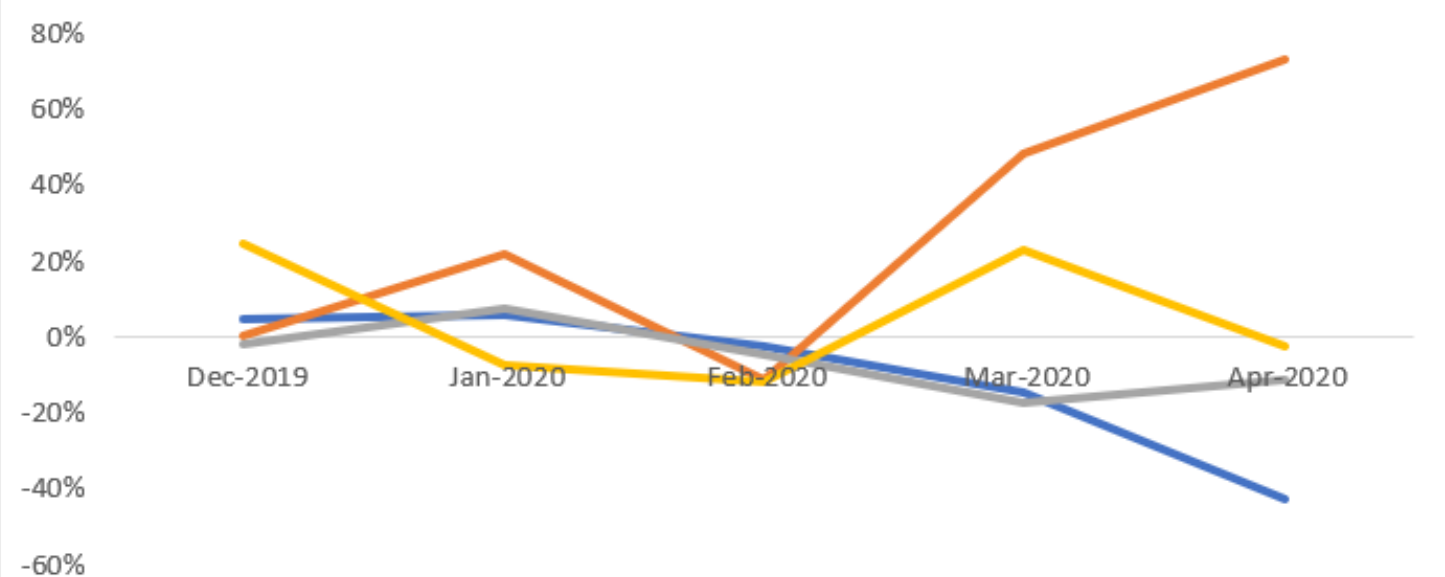

$-60 \%$

Auto $\longrightarrow$ Online education $\longrightarrow$ Personal Care and Beauty without Sanitizer $\rightleftharpoons$ Telecom

Source: https://ads.google.com/intl/en_in/home/tools/keyword-planner/

IV.

\section{DISCUSSIONS}

COVID-19 has changed the way the "World works", just like the Great Depression, dot-com bubble, and the 2008 financial crash did in the past. The question on everyone's mind is, 'what is the new normal?'

The COVID-19 cases in India are still increasing at a rapid pace with high impact states being Maharashtra, Delhi, Tamil Nadu and Gujarat. From economic and industrial impact perspective these states have approximately $3 \mathrm{X}$ or higher COVID-19 infected population density than that for India overall.

It is established that there will be a fundamental change in how people work, businesses will function, and economies turnaround. The next 12 months will be difficult. Many businesses will struggle, some may even shutdown.
But as with economic adversities of the past, new industries will emerge bringing with it renewed hope of recovery. Eventually, things will go back to "normal". And this will be the "New Normal".

As businesses shut down, cancellations and postponements of public activities will drastically reduce consumer spending across countries and business domains. India is now observing multiple economic shocks surfacing from the COVID-19 pandemic. In no particular order, they are - an initial supply side shock imposed due to lockdowns, a fiscal shock due to public health emergency and overall decline in all economic fronts.

The financial markets at the moment are reacting to these shocks in continuum and are likely to remain extremely volatile for a significant period of time; at the very least till the number of infected cases start coming down 
across country. If the situation continues with no vaccines the financial situation will further deteriorate and will be worse than what we have seen during 2008-2009 financial crisis.

Despite monetary-policy supported stimulus by Government of India and Reserve Bank, Nation is still under financial turmoil and would need further intervention to address the structural economic fallout due to COVID-19.

As already stated, during these times of uncertainty, forecasting with high accuracy is difficult, as one might not be able to build stable underlying assumptions of forecasting growth models.

Observations from research of economists Hugo Erken, Raphie Hayat and Kan Ji also suggest: a substantial economic slowdown, estimated a global growth level of $1.6 \%$ which is around $0.8 \%$ less than the previous OECD estimate of $2.4 \%$. Assessing these simulations and forecasts for multiple economic parameters we have built growth simulations for businesses and categories in India, thereby giving a quantitative estimation to the market scenarios. Growth in India across sectors might significantly change if the global containment of virus doesn't happen. It is unclear if the containment will only happen when vaccines become common.

There are explicit negative-externality costs to some critical Indian sectors including agrochemicals, electronic equipment, automotive components, etc, while offering a thin silver lining of opportunity to some sectors (textiles, garments, etc.) to boost domestic production and replace broken parts of supply chain networks.

Most employment created today, remains largely visible in form of contractual jobs with many new jobs created in the "gig economy" segment (Uber, Ola, Swiggy, Zomato etc.). Pandemic crisis resulting in shutting down or slashed operational level(half/ third) of the capacity restaurants, movie theatres, and imposing restrictions on mobility of people, renders many jobless who have no alternative source of income in hand.

Less consumer spending is already hitting each sector hard, and with a weakening of aggregate demand, a vicious Keynesian cycle of low investment and high unemployment will result in recession which will further slow the business recovery.

Further Government intervention is required to minimize the risk of recession, as also stated by the IMF chief economist Gita Gopinath, "Households and businesses hit by supply disruptions and a drop in demand could be targeted to receive cash transfers, wage subsidies, and tax relief, helping people to meet their needs and businesses to stay afloat. Italy has extended tax deadlines for companies in affected areas and broadened the wage supplementation fund to provide income support to laid-off workers, Korea has introduced wage subsidies for small merchants and increased allowances for homecare and job seekers, and China has temporarily waived social security contributions for businesses. For those laid-off, unemployment insurance could be temporarily enhanced, by extending its duration, increasing benefits, or relaxing eligibility. Where paid sick and family leave is not among standard benefits, governments should consider funding it to allow unwell workers or their caregivers to stay home without fear of losing their jobs during the epidemic." $[16]$

India needs to carefully monitor the consumption spends along with unemployment rate for designing and implementing the policies. The future of the businesses heavily depends on the measure taken by financial institutions to revive demand and supply cycle in the country. Indian economy is both huge and diverse. The policy response will have to be mindful of this diversity. Only then can suitable measures be applied where they are needed.

What does a contraction in GDP mean in real life? Incomes will drop. Jobs will be lost. However, the impact of the contraction will vary across sectors, states, even social groups. This knowledge is indispensable for an effective policy intervention.

For example, it can be expected that at least two sectors; agriculture and government, will not see a contraction. In 2019-20, these two sectors had a share of almost $30 \%$ in total Gross Value Added (GVA). This means that the economic pain will be far more severe in the rest of the economy. ${ }^{[17]}$

The non-farm, non-government economy contains many sub-sectors. A contraction in each sub-sector will have different impact across states and jobs. For example, the non-farm, non-government sector had a share of $86 \%$ in Gross State Value Added (GSVA) for Delhi. This share was $56 \%$ for Madhya Pradesh, and only 38\% for Arunachal Pradesh. This means that Delhi's economic pain will be far more severe than Arunachal Pradesh's. Supporting finance will probably cushion the not-so-poor, and the sectors which depend on their demand. ${ }^{[17]}$

A useful way to measure job losses which is an important part of our simulation in finding the growth of categories and businesses during a contraction is by using what is referred to as employment elasticity of output in economics. The concept captures the idea that for the same amount of growth, job creation varies across sectors. This also means that job losses during a contraction phase will vary across sectors.

Hence we observe, difference in the response for different categories and markets/states, to each of the analyzed economic parameter, (as shown in- figure 3, figure 7 and table 5) the recovery strategy needs to be planned differently for each category and states.

As suggested by the economists Liquidity is another relevant parameter, and is expected to remain tight as the cost of borrowing in real terms will jump upwards Banks and financial institutions will be under immense pressure as the fear of NPAs, insolvency and bankruptcies increase multifold.

The above parameters, their simulations and their probable estimates will help economy and businesses recover. Basis these we have tried and find the qualitative and quantitative explanations and measure the paths and rate of recoveries.

The recovery plans must be tackled in a sequential way, starting with assessing the COVID-19 breakout across India and then strategizing the economic revival basis the expected recovery time, direction and casualties. 
Table 6: Category relative recovery ranking

\begin{tabular}{|c|c|c|}
\hline Sectors & Indexed \% Change & Rank \\
\hline Nifty Pharma (NIPHARM) & $\begin{array}{r}31 \% \\
\end{array}$ & \\
\hline Nifty FMCG (NIFTYFMCG) & $16 \%$ & \\
\hline $\begin{array}{l}\text { Nifty India Consumption } \\
\text { (NIFTYCONS) }\end{array}$ & $11 \%$ & 1 \\
\hline Nifty Energy (NIFTYENR) & $7 \%$ & \\
\hline Nifty IT (NIFTYIT) & $5 \%$ & \\
\hline TELECOM Sensex Nifty Indexed & $5 \%$ & 2 \\
\hline Nifty Auto (NIFTYAUTO) & $-3 \%$ & \\
\hline Nifty Financial Services & $-7 \%$ & \\
\hline Nifty Media (NIFTYMED) & $-13 \%$ & 3 \\
\hline Nifty Realty (NIFTYREAL) & $-22 \%$ & 4 \\
\hline
\end{tabular}

In these times of uncertainty and immense variability, the numbers might keep changing but the consumer intent and investors sentiments patterns can be used to further gauge the pace and direction to build business strategy for recovery in an optimal way.

Analyzing the stocks data, the direction and pace of the recovery is identified by different sectors of economy (refer Table 5 and Table 6):

a. Pharma stock prices grew by approximately 31 per cent during the COVID-19 times, as the need for the vaccines to tackle COVID-19 is at its peak and thus will continue to be the top most sector to recover. Firms dealing in Chemicals and Pharma will see a jump due to increased demand for disinfectants, drugs and medicines.

b. With the companies which deals in personal care, packaged foods etc. FMCG is a sector with a decent recovery pace, as during the COVID-19 times the index has seen 16 per cent jump in the stock prices as compared to non-COVID-19 times. Further analyzing sales as simulated by our macroeconomic simulator we see that the Personal Care and Beauty Segment will grow at $\sim 5$ per cent. But with more than 3-5 months of reduced or no sales (Blackout period) the growth seems to be 45-50 per cent lower than that of the expected YOY growth for this financial year as expected before the COVID-19 onset. While the Food and Staple segment will see a YOY growth of 9.3 per cent as compared to 11.6 per cent forecasted at the start of the year.

c. With multiple lockdowns implemented nationally to curb the COVID-19 spread, many businesses have announced work from home and inculcated tech and digitization in the day to day chores, Telecom sector has seen a huge jump in the internet consumption. The same can be seen in the stocks movement for telecom index and foreign investments received in the telecom sector. Telecom sector with the infusion of stock market analysis, macroeconomic simulations and the consumer search data, is expected to grow almost at the same pace of 0.6 per cent- 0.8 per cent in revenues this year. Digital \& Internet Economy: Online based products \& services companies will find new takers. Ed-tech and Online Education along with firms involved with online-skill development and Online groceries. Sudden spike in the demand for Content is also observed, with digital content being in demand more than ever. d. The hardest hit sectors where the recovery seems to be much slower basis the stock movements and our macroeconomic simulation cross validated with the consumer purchase intent and category penetration data will be Automobiles, Financial services and Realty.

e. From the past few years we have seen drops in the growth in Automobile segment and during these times further revival of the category seems to be difficult. Stock prices dropped by 3 per cent and the simulated sales growth nearing -35 per cent to -40 per cent, approximately 120 per cent lower YOY growth from last year.

f. Other hit sectors include: ${ }^{[18]}$

i. Apparel \& Textile will get hit adversely due to disruption in labor supply, raw material unavailability, working capital constraints and restricted demand due to limited movement of people and purchasing ability.

ii. Aviation \& Tourism is one sector which has the highest probability of going under without direct government intervention. In the next 12 months, it's highly unlikely people will travel for leisure apart from very essential travel.

iii. $\quad$ Shipping and Non-Food Retail - Non-Food retail chains and global shipping businesses will find this 12 month period very challenging.

iv. Building \& Construction businesses are generally leveraged and hence will face the dual challenges of high-interest payments and lack of sales.

The stock markets and balance sheets for these sectors has helped us monitor the monetary performances of the companies and businesses and thereby sectors as whole. The Debt to Equity (D/E) Ratio is one such metric used to evaluate a company's financial leverage. The $\mathrm{D} / \mathrm{E}$ ratio is an important metric used in corporate finance. It is a measure of the degree to which a company is financing its operations through debt versus wholly-owned funds. More specifically, it reflects the ability of shareholder equity to cover all outstanding debts in the event of a business downturn.

Comparing Debt to Equity Ratio of Sectors: ${ }^{[18]}$

1. Real Estate: 0.86

2. Information Technology: 0.11

3. Consumer Staples (FMCG Food): 0.49

4. Financials (Investment Banking and Brokerage): 0.083 A good debt to equity ratio is around 1 to 1.5 . However, the ideal debt to equity ratio will vary depending on the industry because some industries use more debt financing than others. Capital-intensive industries like the financial and manufacturing industries often have higher ratios that can be greater than $2 .{ }^{[19][20]}$ If a debt to equity ratio is lower which is less than one for almost all the major sectors, closer to zero, this often means the business hasn't relied on borrowing to finance operations. Investors are unlikely to invest in a company with a very low ratio because the business isn't realizing the potential profit or value it could gain by borrowing and increasing operations. 


\section{CONCLUSIONS}

COVID-19 has impacted the entire Indian economy, with its adverse effect from complete lockdown to partial unlock that has resulted disruption in the entire supply chain, demand is all in vain and we observe a huge shift in consumer behavior. This is now considered as an economic and humanitarian crisis. There is a trade-off for the policymakers to either save the economy from freefall or contain the Pandemic, save important lives and prevent further transmission. ${ }^{[21]}$ Impacting complete business dynamics, with many businesses running out of cash. As the uncertainty prevails and situation worsens the businesses are in dire need of data driven strategic guidance system to effectively channelize their recovery.

We have studied the impact of COVID-19 on businesses and domains with respect to stocks movement data and sales simulations using the economic parameters we can derive the path, pace and patterns of recovery duly validated by the demand proxy. The results of the study include the short-term recovery patterns for a whole range of domains including Telecom, Pharma, FMCG, Automobile, Realty etc. and their growth projections for the FY 20-21 taking into account the economic projections and variability in the parameters which can help companies better plan their short term and long term goals and thus revive their businesses.

Hence from the study we can conclude that Pharma is the least hit category and will lead the path to recovery followed by FMCG-essential goods and personal care segment. The hardest hit segments would include Automobile, Realty, and Media which will need the economy to stabilize before they can see any positive sign of recovery in the market.

\section{ACKNOWLEDGMENT}

We would like to extend our gratitude to Mr. Vinod Pandya (Former Special Secretary Expenditure, Finance Department, Government of Rajasthan. Former Member, Rajasthan Electricity Regulatory Commission.), Mrs. Kaumudi Gupta (Retd. Director Pensions, Finance Department, Government of Rajasthan), Mr. Yogesh Gupta (Retd. Chief Engineer, PWD, Government of Rajasthan. Former Professor, HCMRIPA, Government of Rajasthan), Dr. Aswini Kumar Mishra (Associate Professor and Head, Department of Economics, BITS Pilani KK Birla Goa Campus) for reviewing the paper, methodology and business insights.

Nobody has been more important to us in the pursuit of this project than the members of our family. We would like to thank our parents, partners and children, who provide unending inspiration and support.

\section{REFERENCES:}

[1] Wikipedia (2020, June 22). Economic impact of the COVID-19 pandemic in India. Retrieved from https://en.wikipedia.org/wiki/Economic_impact_of_the_COVID19_pandemic_in_India

[2] Vyas, Mahesh (21 April 2020). "Unemployment rate touches 26\%". Centre for Monitoring Indian Economy (CMIE). Retrieved 24 April 2020.
[3] Goyal, Malini (22 March 2020). "Covid-19: How the deadly virus hints at a looming financial crisis". The Economic Times. Retrieved 23 March 2020.

[4] Research, Centre for Policy. "Podcast: How has India's lockdown impacted unemployment rates and income levels?". Scroll.in. Retrieved 24 April 2020.

[5] The Hindu BusinessLine (2020, April 02). Covid-19 lockdown estimated to cost India $\$ 4.5$ billion a day: Acuité Ratings. Retrieved https://www.thehindubusinessline.com/economy/covid-19lockdown-estimated-to-cost-india-45-billion-a-day-acuitratings/article31235264.ece<11 April 2020>.

[6] The Hindu BusinessLine (2020, March 25). Experts peg India's cost of coronavirus lockdown at USD 120 bn. Retrieved from https://www.thehindubusinessline.com/economy/experts-pegindias-cost-of-coronavirus-lockdown-at-usd-120bn/article31160115.ece The Hindu @businessline. Retrieved 25 March 2020.

[7] Iyer, Sriram (2020, April 18). Lockdown relaxation- more than half of India's economy may reopen from Monday, says Nomura. Business Insider. Retrieved from https://www.businessinsider.in/policy/economy/news/lockdownrelaxation-more-than-half-of-indian-economy-may-reopen-frommonday-april-20/articleshow/75220299.cms

[8] Biman.Mukherji (23 March 2020). "Coronavirus impact: Indian industry seeks relief measures to aid economy". Livemint. Retrieved from

https://www.livemint.com/companies/news/coronavirus-impactindian-industry-seeks-relief-measures-to-aid-economy11584904435575.html.

[9] Blin, O., Ielpo, F., Lee, J., \& Teiletche, J. (2017). 12 - A Macro RiskBased Approach to Alternative Risk Premia Allocation. In E. Jurczenko (Ed.), Factor Investing (pp. 285-316): Elsevier.

[10] Tamegawa, K. (2013). Constructing a Small-Region DSGE Model ISRN Economics, 2013, 825862. doi:10.1155/2013/825862

[11] Wikipedia. Economic indicator. Retrieved from https://en.wikipedia.org/wiki/Economic_indicator

[12] Fisher, Sarah (2019, July 09). "Economic Indicators: Definition, Types and Usage". Retrieved from https://finance.yahoo.com/news/economic-indicators-definitiontypes-usage-185925254.html

[13] Harper R, David (2019, November 19). "Forces That Move Stock Prices". Retrieved from https://www.investopedia.com/articles/basics/04/100804.asp

[14] International Monetary Fund (2020, June 19). Policy Responses to COVID-19. International Monetary Fund, 700 19th Street, N.W. Washington, D.C. 20431. Retrieved from https://www.imf.org/en/Topics/imf-and-covid19/PolicyResponses-to-COVID-19

[15] Schwab Trading Insights (2018, June 11). "Macro-economic factors of fundamental analysis". Retrieved from https://www.cnbc.com/advertorial/2018/06/11/macro-economicfactors-of-fundamental-analysis.html

[16] Reuters (2020, March 09). "IMF says governments should offer cash transfers, tax relief to ease coronavirus effects". Retrieved from https://finance.yahoo.com/news/imf-says-govts-offer-cash131252315.html

[17] Kishore, Roshan and Jha, Abhishek. Hindustan Times (2020) "Economic impact of Covid-19 pandemic to vary in sectors". Retrieved from https://www.hindustantimes.com/indianews/economic-impact-of-covid-19-pandemic-to-vary-insectors/story-DIWjwnBZoON7ZUvgSMSFOL.html

[18] Rastogi, Siddhartha (2020, April 29). "COVID-19 Impact on the Indian Economy". Retrieved from https://blog.smallcase.com/thenew-normal-analysis-of-covid-19-on-indian-businesses-sectorsand-the-economy

[19] Tyre, Dan. "Debt to Equity Ratio, Demystified". Retrieved from https://blog.hubspot.com/sales/debt-equity-ratio

[20] Hayes, Adam (2020, April 27). "Debt-To-Equity Ratio - D/E". Retrieved from https://www.investopedia.com/terms/d/debtequityratio.asp

[21] Gaurav, Amit (2020). The Economic Cost of 2020 Pandemic: Overview of socio-economic Impact of COVID-19 and lessons from Past Pandemics. Independently Published. ISBN-13: 9798642674307. 